\title{
Mushroom Phorid Flies-A Review
}

\author{
María J. Navarro ${ }^{1, *(\mathbb{D})}$, Lucía Adriana Escudero-Colomar ${ }^{2}$, Jaime Carrasco ${ }^{3,4, *}$ and Francisco J. Gea ${ }^{1}$ (D) \\ 1 Centro de Investigación, Experimentación y Servicios del champiñón (CIES), Quintanar del Rey, \\ 16220 Cuenca, Spain; fjgea.cies@dipucuenca.es \\ 2 IRTA (Institute of Agrifood, Research and Technology)-Sustainable Plant Protection, Mas Badia, \\ Canet de la Tallada, S/N, 17134 Girona, Spain; adriana.escudero@irta.es \\ 3 Centro Tecnológico de Investigación del Champiñón de La Rioja (CTICH), 26560 Autol, Spain \\ 4 Department of Plant Sciences, University of Oxford, South Parks Road, Oxford OX1 4BH, UK \\ * Correspondence: mjnavarro.cies@dipucuenca.es (M.J.N.); jaime.carrasco@plants.ox.ac.uk (J.C.); \\ Tel.: +34-967-496-198 (M.J.N.)
}

\begin{abstract}
Diptera are among the most serious arthropod pests affecting mushroom crops. Phorid flies, especially Megaselia halterata, have traditionally been globally considered as a minor pest, although they are a very important problem on Spanish mushroom farms. The concerns with respect to the phorid fly populations have recently increased, notably jumping from being a minor to major pest in India, UK and the USA, where yield losses ranging between $10 \%$ and $40 \%$ were reported. This review updates and summarizes the available literature regarding mushroom phorid populations, stressing the natural distribution of phorids and their seasonal distribution, their biology within the growing substrates and the initial sources of infestation on mushroom farms. Moreover, the review also highlights the scarce available tools for their control and the current alternatives to chemical products.
\end{abstract}

check for updates

Citation: Navarro, M.J.;

Escudero-Colomar, L.A.; Carrasco, J.; Gea, F.J. Mushroom Phorid Flies-A Review. Agronomy 2021, 11, 1958. https://doi.org/10.3390/agronomy 11101958

Academic Editor: Siegrid Steinkellner

Received: 31 August 2021

Accepted: 23 September 2021

Published: 29 September 2021

Publisher's Note: MDPI stays neutral with regard to jurisdictional claims in published maps and institutional affiliations.

Copyright: (C) 2021 by the authors. Licensee MDPI, Basel, Switzerland. This article is an open access article distributed under the terms and conditions of the Creative Commons Attribution (CC BY) license (https:// creativecommons.org/licenses/by/ $4.0 /)$.
Keywords: edible fungi; mushroom flies; infestation sources; biology; chemical control; biological control

\section{Introduction}

Mushroom crops are susceptible to a variety of pests and diseases that may affect the yield and quality of production [1,2]. Dipteran species (phorid and sciarid flies) are among the main arthropod pests affecting the cultivation of A. bisporus throughout the world [3-6]. Mushroom yield losses are either directly due to the larvae of mushroom flies feeding on the mycelia or carpophores, or to other pests and diseases vectored by these flies [7]. Reported evidence points to the transport of spores of different species of pathogenic fungi by mushroom flies [8-14]. Similarly, phorids as well as sciarids were described as vectors of pathogenic mites [15-18].

Mushroom sciarids of the genus Lycoriella (Frey) (Diptera: Sciaridae) were traditionally considered as the most significant pests of cultivated mushrooms regardless of where production occurs. Up to five times as many sciarids as phorids are frequently caught [5,19-23]. The sciarid biology and the incidence on mushroom crops, in addition to the pest control through chemical treatments and alternative biological methods, were reviewed [20]. Cecidomyids and phorids, while also present in mushroom facilities, have usually been considered as minor pests, which explains why they have received less attention. Remarkably, crop losses associated with the incidence of phorids ranged from $10 \%$ to $40 \%[4,24,25]$. During an 18-month-period survey conducted on 24 growing mushroom crops in the Castilla-La Mancha region (south-eastern Spain), a ratio of 4:1 between phorids (Megaselia halterara (Wood)) and sciarids (Lycoriella auripila Winnertz) were caught [26]. The predominance of phorid flies over sciarids in mushroom facilities was also reported in Turkey [7], the Netherlands [27], India [28,29] and, more recently, the USA, where phorid 
fly populations have markedly increased from a minor to major pest status on mushroom farms located in Pennsylvania [30-32].

The review compiles and summarizes the information regarding mushroom phorid populations published to date, highlighting the natural distribution of phorids and their seasonal distribution, their biology within the mushroom substrates and the main initial sources for infestation on mushroom farms. Moreover, the review also digs into the scarce tools available for their control and the alternatives to the chemical treatments currently applied.

\section{Natural Distribution of Phorid Flies}

The genus Megaselia Rondani (Diptera: Phoridae) includes about $45 \%$ of all phorid species. Larvae of these flies usually develop in decomposing organic material and plant tissues; moreover, many phorid fly species are parasitoids or parasites of invertebrates and vertebrates, including humans [33]. Phorid adults are opportunists and migrate between suitable habitats [5], but few species feed on cultivated mushrooms. Phorids have been considered mushroom pests since 1953, when huge populations of Megaselia halterata were registered on British mushroom-growing farms [34]. Megaselia halterata is perhaps the most prevalent phorid species in the mushroom-growing areas worldwide [35], overtaking Megaselia nigra (Meigein), which was the main phorid fly in the first years of the 20th century [34,36-38]. Other identified species associated with growing mushroom crops include: Megaselia flavinervis (Malloch), Megaselia agarici (Lintner), Megaselia iriguoiana (Felt.) and Megaselia bovista Gimmerthal [38,39], Megaselia sandhui (Disney) [3,40] and Megaselia tamilnaduensis Disney [41].

Larvae of these species are obligatory mycetobionts with inconspicuous heads and mouthparts adapted to feeding on mycelia [42-44]. While M. nigra was found on many fungus species among five different families [45], M. halterata feeds on few species, and its presence was noted on Pleurotus spp. farms [29,46,47] and on Agaricus bisporus (Lange) Imbach and Agaricus bitorquis (Quél.) Sacc crops [48]. White et al. [49] reported cultivated A. bisporus to be more susceptible to phorid Megaselia halterata than wild species. Moreover, within the genus Agaricus, M. halterata is strongly attracted for some specific strains [40]. Smith et al. [50] established, in a panel of twelve isolates from the genus Agaricus, a significant separation between resistant and susceptible isolates to the oviposition of adult females and larval development in mushroom compost. Molecular identification of these Agaricus strains revealed two major cluster groups: strains supporting the development of M. halterata populations and those that did not. Agaricus strains resistant to M. halterata, as described by their olfactory profile [4], were postulated as candidates for breeding programs with commercial $A$. bisporus strains.

\section{Seasonal Life History}

Few studies have evaluated the incidence of phorid flies inside mushroom facilities throughout the year. Erler and Polat [7] revealed that $M$. halterata was the main species from April to October on Turkish mushroom farms. A similar study in Ireland found that phorid captures in traps increased in late summer and early autumn, while they underwent a period of inactivity from December to March $[5,19]$. Recently, the population densities of adult $M$. halterata inside mushroom houses in Pennsylvania, USA were described to follow a seasonal pattern similar to the Irish model: demonstrating low activity from winter to spring, increasing during the summer and finally peaking over the autumn [30]. Low temperatures, high-speed wind and abundant rainfall were postulated as the main weather factors affecting phorid activity; moreover, the effect of light intensity over fly flying was also reported as a critical factor [51]. However other studies did not find a correlation between meteorological data and the rate of pest increase [52]. Kumar and Sharma $[53,54]$ related maximum phorid fly populations with temperatures of $18.5-25^{\circ} \mathrm{C}$ and described a positive correlation between the phorid population and temperature. Shikano et al. [32] described high phorid activity under weather conditions out of this 
favorable temperature range, suggesting that this population had principally developed inside climate-controlled mushroom houses. Mazin et al. [31] also related the fly activity with daylight levels, hypothesizing that establishing temperature and daylight thresholds for phorid flight activity could be useful for developing integrated pest management (IPM).

\section{Sources of Initial Infestation in Mushroom Crops}

Some of the most commonly cultivated mushrooms use compost as a nutritional substrate for growing. The segregation of compost manufacture, in composting facilities, from mushroom farms may reduce cross-contamination of pests and diseases. In an in-depth study of compost production as a significant source of fly pests, Jess et al. [5] advised that during the pasteurization stage, all compost mass must be exposed to temperatures high enough to kill pests. Nonetheless, some phorid adults were collected in the bagging area, representing a minor risk for the transportation of adult flies to mushroom cultivation sites within bags of ready-to-use compost. However, the limited numbers of adult M. halterata detected suggested that correctly pasteurized compost was an unlikely initial source of this insect pest.

The cultivation of $A$. bisporus is a phased process in which fungal mycelia is grown in pasteurized compost, and a casing layer of peat or peat substitute is then added (casing practice) to stimulate the production of mushroom fruit bodies [50]. Female phorids are normally attracted to volatiles produced by developing mycelia [52,55,56]. As described by Tibbles et al. [4], M. halterata adult females were attracted to composted substrates containing $A$. bisporus mycelia, and the extent of the response increased with the aging of mycelium in the substrate. Conversely, Shikano et al. [32] reported that a similar number of flies emerged from freshly inoculated and 14-day-spawned compost. Tibbles et al. [4] and Kumar [40] observed that raw compost (without $A$. bisporus mycelia) could repel adult female $M$. halterata, and that these flies were more attracted to 14-day-spawned substrates (fully colonized). However, the highest number of emerging M. halterata was obtained from a compost spawned for four days. Therefore, the presence of phorid flies could assess the quality of the compost as a potential oviposition site after it is located. Female fertility was also linked to daylight and to the presence of a high concentration of carbohydrates in growing substrates $[38,51,57]$. M. halterata focused its flight activity outside the mushroom facilities, over turf areas, for mating purposes which means that a proportion of the $M$. halterata adults may leave mushroom houses to mate, and then re-enter the mushroom houses to lay eggs [31]. The most intense flight activity was detected in the afternoon until midnight during the seasons with higher temperatures $\left(27-37^{\circ} \mathrm{C}\right)$, but in lower temperature seasons $\left(23-25^{\circ} \mathrm{C}\right)$, activity ceased after sunset [31]. Although some eight-carbon volatile molecules were postulated in the past, the volatile compounds responsible for attracting adult $M$. halterata have yet to be determined $[55,56]$. Some studies recently suggested that 1-octen-3-ol, a common mushroom alcohol emitted by several fungal fruiting bodies, acts an oviposition deterrent of some pests due to the close association of these odors with potential pathogens [58-60]. These findings suggest that volatiles could be used on mushroom farms as a chemical lure to attract adult females away from spawned compost.

\section{Biology of Phorid Flies}

Phorid female oviposition occurs 7-12 days after spawning, or 4-8 days after casing $[61,62]$. Larvae hatching from the eggs continue their development until they are fully mature, when the larvae stop feeding and migrate upward to the top of the compost or casing layer where they pupate $[3,62]$. As a short period of the phorid life cycle is spent in a larval stage [63], yield reduction directly due to larval feeding is only problematic at very high fly densities (14-17 larvae per $30 \mathrm{~g}$ of compost). The life cycle continues with adult emergence; males emerge before females and form into swarms, awaiting the emerging females. High humidity and cool temperature environmental conditions (HR > 75\% and $15^{\circ} \mathrm{C}$ ) benefit fly longevity, with females being more influenced than males [32]. Hussey [63] established a pre-mate period of five days. A period of flight is required 
before mating, and females need carbohydrates for egg fertilization [64,65]. After mating, females have a pre-oviposition period of about thirteen hours [3]. The number of eggs per females is variable; the average numbers of offspring flies produced per parental female fly decrease linearly with parental density, thus avoiding larval competition for space and food $[32,64]$. Table 1 summarizes the biology of mushroom phorid flies described in mushroom crops. Once an infestation has established in the substrate, the protected environment of the mushroom house allows populations to be maintained for extended periods [50]. The biology and morphometry of $M$. halterata were extensively described by Lewandoski et al., highlighting a development time of a $M$. halterata generation, from egg to adult, by 16-19 days at $24{ }^{\circ} \mathrm{C}$ [44]. Other studies established this time slightly higher: $22-20$ days at $25-27^{\circ} \mathrm{C}$, respectively, depending on the substrate, casing and spawn-running in the compost [66]. The overall time from hatching to pupation ranged from 12 to 14 days. Pupal development required 5-8 days, representing almost $50 \%$ of the developmental time [44]. Adult emergence was observed after 16 days from hatching. The developmental times of males and females differed significantly $[67,68]$. This concise knowledge is relevant for the application timing of effective control measures, depending on the target stage. Furthermore, understanding the morphological parameters for subsequent developmental stages could help to estimate, using the inverse prediction statistical technique, the most likely point for phorid infestation, and the described biology of the pest, together with the indoors-controlled conditions for mushroom cropping, provides an opportunity for integrated pest management as a control strategy of phorid flies.

Table 1. Biology of mushroom phorid flies associated with mushroom crops.

\begin{tabular}{|c|c|c|c|}
\hline Developmental Stage & Time & Farm Location (Substrates) & Phorid Stages * \\
\hline $\begin{array}{l}\text { Female oviposition (eggs are } \\
0.5-0.7 \mathrm{~mm} \text { long, opaque when } \\
\text { fertilized and transparent when } \\
\text { not, concave and smooth) }\end{array}$ & $\begin{array}{l}\text { 7-12 days after spawning, } \\
\text { or } 4-8 \text { days after casing. After } \\
\text { mating, females have a } \\
\text { pre-oviposition period of about } \\
\text { thirteen hours. Duration of egg } \\
\text { development: } 3-5 \text { days at } 24^{\circ} \mathrm{C}\end{array}$ & Compost or casing layer & \\
\hline $\begin{array}{l}\text { Larvae hatching from the eggs } \\
\text { (M. halterata has white, translucent } \\
\text { and segmented larvae, blunt on } \\
\text { one of the edges and pointed in } \\
\text { the other, of } 4.5 \mathrm{~mm} \text { max. length) }\end{array}$ & $\begin{array}{l}\text { Duration of larvae development: } \\
8-11 \text { days a } 24^{\circ} \mathrm{C}\end{array}$ & $\begin{array}{l}\text { Compost or casing layer. } \\
\text { Migration upward to top compost } \\
\text { or to casing layer }\end{array}$ & \\
\hline $\begin{array}{l}\text { Pupation (phorid pupae are white } \\
\text { initially turning to } \\
\text { brown-yellowish when maturing, } \\
\text { approx. } 2 \mathrm{~mm} \text { length) }\end{array}$ & $\begin{array}{l}\text { Duration of pupa development: } \\
5-8 \text { days at } 24{ }^{\circ} \mathrm{C}\end{array}$ & $\begin{array}{l}\text { Over top layer of compost } \\
\text { and casing }\end{array}$ & \\
\hline $\begin{array}{l}\text { Adult emergence (Adults are } \\
2-3 \mathrm{~mm} \text { long and blackish-brown } \\
\text { in color. They have short } \\
\text { antennae, with only three } \\
\text { segments, and a prominent back. } \\
\text { The wings lack cross venation) }\end{array}$ & $\begin{array}{l}\text { Adult emergence was observed } \\
\text { after } 16 \text { days from hatching. } \\
\text { M. halterata development } \\
\text { duration, from egg to adult, takes } \\
\text { 16-19 days at } 24^{\circ} \mathrm{C} \text {. Other studies } \\
\text { established this time slightly } \\
\text { higher: } 22-20 \text { days at } 25-27^{\circ} \mathrm{C} \text {. }\end{array}$ & $\begin{array}{l}\text { M. halterata flight activity mostly } \\
\text { inside the mushroom facilities; } \\
\text { outside, possibly for } \\
\text { mating purposes }\end{array}$ & \\
\hline
\end{tabular}

* Pictures belong to the CIES, Extracted from [68]. Refs. [3,32,44,61,64,67-69]. 


\section{Chemical Control of Phorid Flies}

Table 2 compiles the literature available with respect to the chemical pesticides used for the control of mushroom flies. Mushroom flies were traditionally controlled by means of insecticidal treatments $[1,2,20]$. The application of pesticides on mushroom crops consists of relatively easy operations to incorporate chemicals into the compost or casing substrates [70]. Pesticides incorporated throughout the composting process are subjected to a high temperature and $\mathrm{pH}$, and a considerable percentage of the dose applied was described to be lost during pasteurization [71,72]. By the end of 20th century, the list of insecticides approved for mushroom use in Europe was large, including the groups of organophosphates (malathion, diazinon, dichlorvos, chlorpyrifos), juvenile hormone analogs (methoprene), benzoylurea (diflubenzuron, triflumuron), pyrethroids (permetrin, deltametrin), carbamamates (carbofuran, bendiocarb) and triazines (cyromazine). However, several examples of the development of resistance were reported [73,74]. 
Table 2. Methods applied for the control of phorid flies in commercial mushroom crops.

\begin{tabular}{|c|c|c|c|c|c|c|c|c|}
\hline Control & Active Ingredient & Target Stage & Substrate & Population Decrease & Phytotoxicity & Advantages & Disadvantages & Ref. \\
\hline \multirow{14}{*}{ Pesticides } & Diazinon & Larvae & Pasteurized compost & Yes & Yes & \multirow{14}{*}{ User-friendly } & \multirow{4}{*}{ Variable phytotoxicity } & [74-78] \\
\hline & Diazinon & Larvae & Pasteurized compost & Yes & No & & & [79] \\
\hline & Diazinon & Larvae & Casing layer & Yes & Variable results & & & [74] \\
\hline & Diazinon & Larvae & Casing layer & Yes & Yes & & & [78] \\
\hline & Aldicarb and chlorpyrifos-ethyl & Larvae & Pasteurized compost & Yes & Yes & & \multirow{4}{*}{$\begin{array}{c}\text { Ecological and sanitary } \\
\text { problems }\end{array}$} & {$[25,80]$} \\
\hline & Methopreno and diflubenzuron & Larvae & Pasteurized compost & Yes & - & & & [74] \\
\hline & Methopreno and diflubenzuron & Larvae & Casing layer & No & - & & & [74] \\
\hline & Triflumuron & Larvae & Pasteurized compost & No & - & & & [74] \\
\hline & Triflumuron & Larvae & Casing layer & No & - & & \multirow{3}{*}{$\begin{array}{l}\text { Residues on } \\
\text { mushrooms at harvest }\end{array}$} & [74] \\
\hline & Bendiocarb & Larvae & Pasteurized compost & Yes & Variable results & & & {$[42,81,82]$} \\
\hline & Bendiocarb and diflubenzuron & Larvae & $\begin{array}{c}\text { Compost and casing } \\
\text { layer }\end{array}$ & Light & - & & & [83] \\
\hline & Pyrethroides & Larvae & $\begin{array}{c}\text { Compost and/or casing } \\
\text { laver }\end{array}$ & Variable results & - & & \multirow{3}{*}{ Variable effectiveness } & {$[20,74]$} \\
\hline & \multirow{2}{*}{$\begin{array}{l}\text { Pyrethroides } \\
\text { Thiamethoxam and/or } \\
\text { pymetrozine }\end{array}$} & Adult & $\begin{array}{l}\text { layer } \\
\text { Wall or space }\end{array}$ & Yes & - & & & [84] \\
\hline & & Adult & $\begin{array}{l}\text { Compost and/or casing } \\
\text { layer }\end{array}$ & Yes & No & & & [82] \\
\hline \multirow{5}{*}{$\begin{array}{l}\text { Entomopathogenic } \\
\text { nematodes }\end{array}$} & Steinernema feltiae & Larvae & Casing layer & No & No & \multirow{5}{*}{$\begin{array}{c}\text { No ecological } \\
\text { problems } \\
\text { No phytotoxicity } \\
\text { No residues }\end{array}$} & Variable effectiveness & {$[85,86]$} \\
\hline & S. feltiae & Larvae & Casing layer & Yes & No & & \multirow{4}{*}{$\begin{array}{l}\text { Unstable biological } \\
\text { activity } \\
\text { Incompatible with } \\
\text { other products }\end{array}$} & {$[6,19,25]$} \\
\hline & Steinernema carpocapsae & Larvae & Casing layer & Yes & No & & & [87] \\
\hline & S. feltiae/S. carpocapsae & Larvae & Casing layer & $\overline{-}$ & Yes & & & [88] \\
\hline & S. feltiae/S. carpocapsae & Larvae & Casing layer & No & No & & & [86] \\
\hline $\begin{array}{l}\text { Entomopathogenic } \\
\text { bacteria }\end{array}$ & Bacillus thuringiensis & Larvae & Casing layer & Yes & No & $\begin{array}{l}\text { Suitability of the } \\
\text { subtrates }\end{array}$ & Expensive & {$[6,89,90]$} \\
\hline $\begin{array}{c}\text { Entomopathogenic } \\
\text { fungi }\end{array}$ & Beauveria bassiana & $\begin{array}{l}\text { Inmature and adult } \\
\text { stages }\end{array}$ & Bioassays & Variable results & - & Potential use & - & [93] \\
\hline \multirow{3}{*}{ Plant Extracts } & \multirow{3}{*}{$\begin{array}{c}\text { Azadirachtin } \\
\text { Pimpinella anisum and Origanum } \\
\text { onites } \\
\text { Garlic extract }\end{array}$} & Larvae & Casing layer & Yes & - & \multirow{3}{*}{$\begin{array}{l}\text { No residues } \\
\text { Many use options } \\
\text { (repellent effect) }\end{array}$} & - & [25] \\
\hline & & Larvae & Casing layer & Yes & No & & \multirow{2}{*}{ Hard to apply } & {$[25,94]$} \\
\hline & & Adult & Bioassays & Yes & - & & & [95] \\
\hline \multirow[t]{3}{*}{ Growing maneuvers } & \multirow{3}{*}{$\begin{array}{l}\text { Fly exclusion based on temperature } \\
\text { and daylight thresholds } \\
\text { Black light lamp, equipped with a } \\
\text { plastic sheet treated with a contact } \\
\text { insecticide and installed near the } \\
\text { ventilation holes, prevents the } \\
\text { oviposition } \\
\text { Early interruption of the crop cycle } \\
\text { prevents the spread of the pest. }\end{array}$} & Adult & - & Yes & No & Low cost & \multirow[t]{3}{*}{$\begin{array}{c}\text { Not for high } \\
\text { population levels }\end{array}$} & [31] \\
\hline & & Adult & - & Yes & No & User-friendly & & [69] \\
\hline & & Adult & - & Yes & - & & & {$[18,20,69]$} \\
\hline
\end{tabular}


Diazinon, an organophosphate insecticide, was the first effective ingredient for phorid control registered in the United States for incorporation into compost in 1979. The application rate between 100 and 500 ppm of diazinon to the pasteurized compost was proven as an effective mechanism for controlling phorid flies at the beginning of the crop cycle, although yields could sometimes become adversely affected [74-78]. Lower doses (25 ppm) did not harm the mycelial growth and effectively controlled both phorid and sciarid flies, with enhanced yield [79]. The insecticides aldicarb and chlorpyrifos-ethyl, incorporated in compost, were also proved to be effective to preclude adult emergence and reduce the incidence of sporophore damage by the larvae of $M$. halterata, although a decreasing yield associated with the chemical treatment was also noted [80]. As recently reported, flies preferably enter into the crops after the application of the casing layer on top of the colonized compost [18]. Accordingly, it would be more advisable to apply the pesticide on the casing layer instead of in the compost; regarding time, this would occur approximately 14 days after spawning or 20 days before the harvesting period begins, thus ensuring the safety of the product. The application of diazinon, at relatively low doses (10 ppm), to the casing material was reported as effective against phorids, although with variable phytotoxic effects [74]. Important yield falls were noted at higher rates [78]. Organophosphates (OPs) are among the most commonly used insecticides, and many studies were designed to evaluate the risk of organophosphorus pesticide application to the environment and human health, highlighting the need to look for alternative means to control phorid flies [21,25,26,74,96,97]. In fact, diazinon was excluded from Annex I of the European Register [98] because of its toxicity for non-target organisms and the accumulation of toxic waste in the environment, although its use is still common in other countries.

Alternatively, insect growth regulators (IGRs) were introduced in the last decades of 20th century. These insecticides have been considered as "insecticides of reduced risk" because of their target specificity (primarily juvenile stages of insects) and their low toxicity against the environment. Diflubenzuron, a benzoylurea insecticide which acts as chitin synthesis inhibitor, was the first IGR registered in 1982 for use against mushroom flies in the USA. Methoprene, a juvenile hormone analogue, was the first IGR registered in 1986 in France for use by the mushroom industry. Cyromazine and triflumuron, also chitin synthesis inhibitors, were registered in Australia in 1988 [96]. There are many studies regarding the possible phytotoxic effect of the IGRs on Agaricus mycelium [30,81,83,99-104]; meanwhile, the effectiveness of these active ingredients against phorid flies has been scarcely studied. Methoprene and diflubenzuron, the last one only at high doses, as compost treatments could be useful against mushroom phorids, although their application on the casing layer was not effective [75]. Furthermore, triflumuron was shown to be ineffective against phorid flies in compost or casing treatments. A light control on phorid populations after diflubenzuron treatment, but always with an additional and previous fumigation of the room with bendiocarb, was achieved [83]. Regarding this broad-spectrum carbamate insecticide, the application of bendiocarb on compost was effective against phorids, but it was associated with yield falls [42,81], although other authors did not describe production losses associated with this insecticide [82]. The group of pyrethroid insecticides was also tested against phorid flies and was applied into the substrate with variable results $[20,73]$. Nevertheless, pyrethroids are currently used as an aerosol treatment, for walls or farm spaces by aerosol dispersion to control adults [84]. The recent application of new kinds of insecticides, thiamethoxam and/or pymetrozine, was also described as effective against phorid flies [82].

Of note, the current Directive 2009/128/EC of the European parliament on the sustainable use of pesticides permits few active ingredients to be used in mushroom-growing crops [105]. While the effectiveness of some insecticides suggests their use to control phorid populations, the grower must also consider other associated risks: (a) detrimental effects on the mushroom mycelium, leading to a loss of yield or quality, in addition to harvest delay $[20,88,106],(b)$ the presence of residues in the harvested mushrooms $[77,103,107,108]$ and (c) ecological damage associated with their use $[89,109]$. 


\section{Alternatives to Pesticides for the Control of Mushroom Phorid Flies}

Other methods for controlling mushroom flies are based on the use of (a) biocontrol organisms, such as mites, bacteria and entomopathogenic nematodes, as well as botanicals based on (b) plant extracts and (c) essential oils. The control methods alternative to chemical insecticides used to fight phorid flies are summarized in Table 2.

\subsection{Biological Control Organisms}

\subsubsection{Biological Control by Entomopathogenic Nematodes (EPNs)}

Richardson [110] was the first author to use entomopathogenic nematodes from the genera Steinernema and Heterorhabditis to control mushroom flies. Steinernema spp. nematodes locate and invade fly larvae via the anus, mouth or spiracles, and release bacteria associated with them (Xenorhabdus spp. or Photorhabdus spp.), which provokes the death of the infested flies. Heterorhabitis spp. nematodes have a structure, named a stylet, which they use to drill into the larvae wall. Apart from their lack of compatibility with the insecticides used, the effectiveness of nematodes in mushroom culture depends on other factors such as $\mathrm{pH}$, temperature, moisture and $\mathrm{CO}_{2}$ levels, which may also affect their activity [111-113]. Information about phorid control by nematodes is scarce in the literature. Some authors revealed that S. feltiae (Filipjev) was not effective over M. halterata populations $[85,86]$. However, the effectiveness of $S$. feltiae $\left(3 \times 10^{6}\right.$ infective juveniles (IJ) per square meter applied on casing) after controlled infestation with $M$. halterata proved efficient in decreasing adult emergence by up to $71 \%[6,26,114]$. Regarding treatment with S. carpocapsae (Filipjev), phorid populations can be reduced by up to $73 \%$ when applied on casing soil during the third larval instar at a dose of up to $15 \times 10^{6} \mathrm{IJm}^{-2}$ on casing soil [87]. This concentration was, however, considered too expensive for commercial use [103]. Of note, some authors observed a detrimental effect of treatments involving entomopathogenic nematodes on mushroom mycelia, such as reduced yield in early flushes, depending on the nematode dosage rate [88]. Meanwhile, the effectiveness of a single biocontrol agent can be restricted by biological characteristics of prey species, and therefore the application of a combined treatment can improve control efficacy [87,115]. Navarro and Gea [86], assaying a combined nematode treatment $\left(0.5 \times 10^{6} \mathrm{IJm}^{-2}\right.$ S. feltiae $+0.5 \times 10^{6} \mathrm{IJm}^{-2} \mathrm{~S}$. carpocapsae) against mushroom flies reported no adverse effect on mushroom production, but no reduction in $M$. halterata populations was noted.

\subsubsection{Biological Control by Entomopathogenic Bacteria}

Bacillus thuringiensis $(\mathrm{Bt})$ is one of the main biological control agents used commercially. Products based on this biological agent can contribute to reduced ecological and environmental problems associated with the use of chemical pesticides. This Gram-positive aerobic spore-forming bacterium is capable of producing crystal insecticidal proteins, also known as delta-endotoxin, when ingested by the larvae of susceptible insects, also dipteran larvae. Moreover, their toxins are harmless to humans, vertebrates and plants, as well as being completely biodegradable, and they do not cause the accumulation of toxic products in the environment. Among the limiting factors of using Bt as a bioinsecticide are the costs and ensuring its biological activity, which may vary according to the strain and culture conditions [116]. There are some papers regarding the effectiveness of $B$. thuringiensis var. israelensis (Bti) as a biocontrol agent against L. mali in mushroom crops, but the dosage rate and the timing of application have had only preliminary studies $[96,117,118]$. Regarding phorid control, the effectiveness of an experimental formulation of B. thuringiensis var. israelensis (Bti) reported a similar control of $M$. halterata as diflubenzuron, methoprene or chlorpiryfos-ethyl applications, even with increasing yields $[6,89,90,119]$. It is worth noting that the application of sodium or calcium hypochlorite, sometimes performed on mushroom growth substrates, could interfere with the effectiveness of Bti treatments $[90,120]$. 


\subsubsection{Biological Control by Mites}

Several mite species are effective predators of mushroom pests, especially dipteran larvae [121]. Predatory mites from the genus Hypoaspis (Acari: Hypoaspidae) have demonstrated some potential for the control of sciarids and phorids in small-scale laboratory trials, and the few semi-field trials have provided encouraging but inconclusive results [70,87]. However, the control of phorid flies with $H$. miles mites in has barely been tested. The application of the predatory mite Hypoaspis miles Berlese to commercial mushroom-growing beds did not report detrimental effects on mushroom yield [122,123]. Additional studies regarding doses and application timing should be carried out. Similarly, another species also reported as a feeder on arthropods and their eggs is Parasitus consanguineus Oudemans $\&$ Voigts. This species was investigated for the ability to develop a diet based on eggs and larvae of the phorid $M$. halterata $[91,92]$, indicating that it has potential as a predatory mite for controlling phorid flies. The shorter developmental time of $P$. consanguineus compared to other predatory mites could be considered potentially advantageous for the control of dipteran pests, leading to a rapid increase in the number of mites under optimal conditions. This species kills more fly larvae than it can eat, and it has a preference for live prey [92]. Meanwhile, the effectiveness of the predatory mites could be restricted by temperature as well as by the body size of the pest species [115]. The use of a combined treatment of biocontrol agents could improve control efficacy toward several pest species in comparison with treatment using a single biocontrol agent.

\subsubsection{Biological Control by Entomopathogenic Fungi}

Fungi have a very active secondary metabolism, and some of them, mostly from the fungal divisions Ascomycota and Zygomycota, secrete insecticidal compounds such as cuticle-degrading enzymes which reflects their great potential to be used as biocontrol agents against pests [124]. The fungal bioinsecticide that contains viable spores of Beauveria bassiana (GHA strain), BotaniGard ES, was assayed in button mushroom crops for the control of immature and adult stages of the phorid Megaselia halterata [93]. The laboratory bioassays to evaluate the efficacy reported a certain level of control towards pupae and adults, while eggs and larvae were not susceptible to the infection by the fungi. The preliminary control action reported should be supported by further studies towards an increasing efficacy of the treatments.

\subsection{Control of Phorids by Plant Extracts}

Regarding plant extracts, azadirachtin-based products are strongly advised for use against mushroom flies $[6,25,27,87,96,125]$, although neem extracts were reported to have fungitoxic activity [126]. Azadirachtin is a chemical compound belonging to the limonoid group which is present in seeds from Azadirachta indica (A. Juss), a Melyaceae tree. Neembased products were shown to be active against more than 200 species of insects, including many dipterans, acting as repellents, feeding inhibitors, oviposition deterrents and/or insect growth regulators. The main effect of neem-based products against phorid flies was the interrupted development of larvae, as they failed to develop normally and died, and no adverse effect on mushroom formation, yield or quality of mushrooms was reported [25]. In addition, neem-based products can be used together with entomopathogenic fungi and nematodes [127].

Some hot-water plant extracts, namely Pimpinella anisum L. (Apiaceae) and Origanum onites L. (Labiatae), have shown repellent activity against mushroom flies, while reducing phorid emergence between 60 and 90\%, and almost no adverse effect on mushroom yield [25]. It should be also pointed out that the repellent effect of garlic extract was effective against phorid adults at concentrations of $1 \% v / v$ and above [95]. The interference of the plant extract on the chitinase activity in the integument/body wall of the phorids was also reported as the insecticidal activity related to the application of hot water extracts of Origanum onites and Pimpinella anisum [94]. The use of plant extracts, in conjunction with good management (compost pasteurization, fly screening, fumigation of rooms and 
good hygiene), may reduce the use of chemical pesticides and can be included within an integrated pest management system.

\subsection{Control of Phorids by Essential Oils}

Essential oils, obtained by steam distillation of certain aromatic plants, were traditionally used to protect stored grain and legumes, and to repel flying insects in the home. Recent investigations in several countries confirm that some plant essential oils not only repel insects, but they have contact and fumigant insecticidal actions against specific pests, and fungicidal actions against some important plant pathogens. Moreover, several constituents are available commercially with high purity $(95 \%)$, and essential oil producers and suppliers can often provide chemical specifications for even the most complex oils. Current information indicates that they are safe to the user, although they also could be phytotoxic [128], and the selectivity among invertebrates is not well documented. One of the characteristics of essential oils is their lack of persistence in field conditions. This, a priori, may seem to be a handicap, but it could be useful, granting greater selectivity to the product, since it would respect the non-target species [129]. The insecticidal activity as a fumigant rather than the contact toxicity of essential oils from various plant species against sciarid flies was reported [130,131]; meanwhile, the effect against phorid flies has not been tested yet.

\subsection{Growing Maneuvres and Physical Barriers}

Insect pest control must be applied during the early stages of mushroom production to avoid significant damage and subsequent yield losses [87]; it is during the earliest production phases that control of invertebrate pests is most beneficial in reducing insect populations and preventing crop yield losses. An additional consideration is that the principal insect pests of mushroom crops are multivoltine, and, therefore, effective control of preceding generations will limit population levels in subsequent generations.

Currently, there are few allowed chemical insecticides which are effective against phorid flies, and biological methods are still under discussion. Besides chemical and biological control tools, other methods to reduce fly populations are based on the control of biotic or abiotic factors, as the use of physical barriers or the modification of the environmental conditions [32,132]. The most successful IPM tool that mushroom growers apply at present is fly exclusion [66]. Exclusion can be improved by focusing farm operations around temperature and daylight thresholds when fly activity is at its lowest [32]. Preventing flies from accessing the farm to lay their eggs, at least at the time of fruiting induction, would delay the onset of the first generation of diptera from the growing medium. A black light lamp, equipped with a plastic sheet treated with a contact insecticide, installed near the door and the ventilation windows, could be a good method to prevent the infestation of flies in the substrates [66]. Likewise, early interruption of the crop cycle after harvesting the third flush would prevent the spread of the pest. Such a maneuver not only minimizes the risk of insect entrance from outside to the farm but also reduces the chances of pests spreading on the farm from affected to nearby uninfected crops $[18,20]$, while also contributing to minimize the dispersal of harmful fungal diseases such as the dry bubble (Figure 1). 


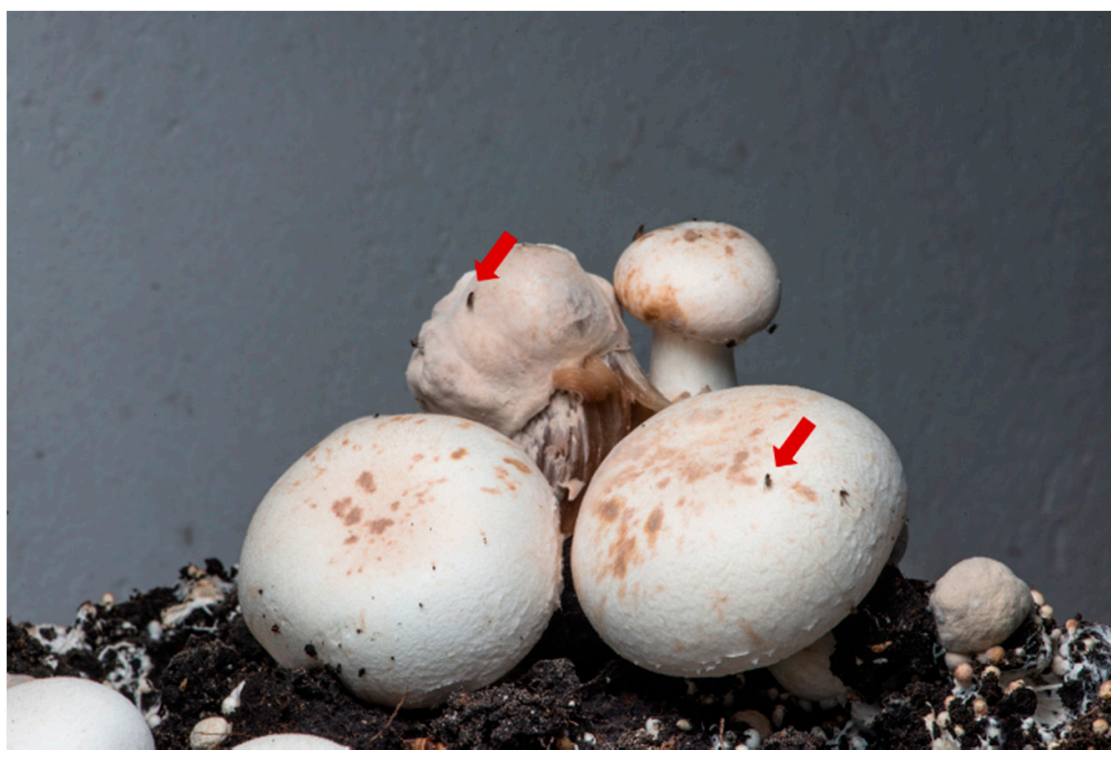

Figure 1. Phorid flies on button mushroom infected by dry bubble (Lecanicillium fungicola). CIES [132].

\section{Conclusions}

Dipteran species are some of the most serious arthropod pests affecting the cultivation of edible mushrooms throughout the world. They provoke yield losses while feeding on crop mycelia or acting as a vector for pest and disease dispersion. Among them, the increasing phorid population is currently considered a major pest on mushroom farms. The study of phorid flies has been scarcely tackled, and, to the authors' knowledge, this is the first review on the topic. This paper compiles and summarizes the literature discussion regarding phorid biology, dispersal and control actions described as a toolbox for the design of useful IPM guidelines to fight phorids in mushroom facilities. Monitoring pest populations, while identifying the initial source and infestation timing, together with the understanding of a correct management of the environmental conditions in the facilities to hinder infestations, is a crucial premise for establishing viable control strategies of this crop pest.

The availability of chemical products to fight phorid flies is increasingly restrictive for mushroom growers due to constraining legislation, environmental concerns and the reduced size of the sector to promote the development of novel and safer alternatives from the pesticide industry. Alternatively, biocontrol organisms and botanicals have a proven efficiency to control phorids, although a value-based product strategy must be analyzed to maximize profit. The current situation suggests combined treatments of chemical and biological products in addition to efficient cultural maneuvers to improve control of mushroom crops and minimize production loss due to the action of phorid flies.

Author Contributions: M.J.N.: conceptualization, writing original—draft preparation, writingreviewing and editing, visualization. L.A.E.-C.: writing original—draft preparation, writingreviewing. J.C.: writing—reviewing and editing, visualization. F.J.G.: conceptualization, writingreviewing. All authors have read and agreed to the published version of the manuscript.

Funding: This research was funded by MAPA (Spain) and INIA (Spain), grant numbers: SC98-011C3-1, RTA01-017-C3-1 and RTA04-091.

Data Availability Statement: Not applicable.

Conflicts of Interest: The authors declare no conflict of interest. 


\section{References}

1. $\quad$ Fletcher, J.T.; Gaze, R.H. Mushroom Pest and Diseases Control; Manson Publishing Ltd.: London, UK, 2008.

2. Rinker, D.L. Insect, mite and nematode pests of commercial mushroom production. In Edible and medicinal Mushroom: Technology and Applications; Zied, D.C., Pardo-Giménez, A., Eds.; Wiley-Blackwell: Chichester, UK, 2017; pp. 221-237.

3. Sandhu, G.S.; Bhattal, D.S. Biology of phorid fly, Megaselia sandui Disney (Diptera: Phoridae) on temperate mushroom. In Cultivating Edible Fungi; Wuest, P.J., Royse, D.J., Beelman, R.B., Eds.; Elsevier: Amsterdam, The Netherlands, 1987 ; pp. 395-404.

4. Tibbles, L.L.; Chandler, D.; Mead, A.; Jervis, M.; Boddy, L. Evaluation of the behavioural response of the flies Megaselia halterata and Lycoriella castanescens to different mushroom cultivation materials. Entomol. Exp. Appl. 2005, 116, 73-81. [CrossRef]

5. Jess, S.; Murchie, A.K.; Bingham, J.F. Potential sources of sciarid and phorid infestations and implications for centralised phases I and II mushroom compost production. Crop. Prot. 2007, 26, 455-464. [CrossRef]

6. Erler, F.; Polat, E.; Demir, H.; Cetin, H.; Erdemir, T. Evaluation of Microbial Products for the Control of the Mushroom Phorid Fly, Megaselia halterata (Wood). J. Èntomol. Sci. 2009, 44, 89-97. [CrossRef]

7. Erler, F.; Polat, E. Mushroom cultivation in Turkey as related to pest and pathogen management. Isr. J. Plant Sci. 2008, 56, 303-308. [CrossRef]

8. White, P.F. Spread of the mushroom disease Verticillium fungicola by Megaselia halterata. Prot. Ecol. 1981, 3, 17-24.

9. Geels, F.P.; van de Geijn, J.; Rutjens, A.J. Pests and diseases. In The Cultivation of Mushrooms; van Griensven, L.J.L.D., Ed.; Darlington Mushroom Laboratories Ltd.: Rustington, UK, 1988; pp. 361-422.

10. Kumar, S.; Sharma, S.R. Transmission of parasitic and competitor moulds of buttons mushroom. Mushroom Res. 1998, 7, 25-28.

11. Clift, A.; Shamshad, A.; Terras, M.A. Flies and dry bubble on cultivated mushrooms. In Science and Cultivation of the Edible and Medicinal Fungi; Romaine, C.P., Keil, C.B., Rinker, D.L., Royse, D.J., Eds.; State College, The Pennsylvania State University: State Colleg, PA, USA, 2004; pp. 459-464.

12. Shamshad, A.; Clift, A.D.; Mansfield, S. The effect of tibia morphology on vector competency of mushroom sciarid flies. J. Appl. Èntomol. 2009, 133, 484-490. [CrossRef]

13. Cloonan, K.R.; Andreadis, S.S.; Chen, H.; Jenkins, N.E.; Baker, T.C. Attraction, Oviposition and Larval Survival of the Fungus Gnat, Lycoriella ingenua, on Fungal Species Isolated from Adults, Larvae, and Mushroom Compost. PLoS ONE 2016, 11, e0167074. [CrossRef] [PubMed]

14. Coles, P.S.; Mazin, M.; Nogin, G. The Association between Mushroom Sciarid Flies, Cultural Techniques, and Green Mold Disease Incidence on Commercial Mushroom Farms. J. Econ. Ėntomol. 2021, 114, 555-559. [CrossRef] [PubMed]

15. Clift, A.D.; Toffolon, R.B. Biology, fungal host preferences and economic significance of two pygmephorid mites (Acarina: Pygmephoroidae) in cultivated mushrooms, New South Wales, Australia. In Mushroom Science XI. Proceedings of the 11th International Congress of Science and Cultivation of Edible Fungi, Sidney Australia; Nair, N.G., Ed.; International Society for Mushroom Science: Sidney, Australia, 1981; pp. 537-550.

16. Clift, A.D.; Larsson, S.F. Phoretic dispersal of Brennandania lambi (Krczal) (Acari: Tarsonemida: Pygmephoridae) by mushroom flies (Diptera: Sciaridae and Phoridae) in New South Wales. Aust. Exp. Appl. Acarol. 1987, 3, 11-20. [CrossRef]

17. Keum, E.; Kang, M.; Jung, C. New Record of Arctoseius cetratus (Sellnick, 1940) (Mesostigmata: Ascidae) Phoretic to Sciarid Fly from Mushroom Culture in Korea. Environ. Biol. Res. 2015, 33, 209-214. [CrossRef]

18. Navarro, M.J.; López-Serrano, F.R.; Escudero-Colomar, L.A.; Gea, F.J. Phoretic relationship between the myceliophagous mite Microdispus lambi(Acari: Microdispidae) and mushroom flies in Spanish crops. Ann. Appl. Biol. 2019, 174, 277-283. [CrossRef]

19. Jess, S.; Bingham, J.F.W. The spectral specific responses of Lycoriella ingenua and Megaselia halterata during mushroom cultivation. J. Agric. Sci. 2004, 142, 421-430. [CrossRef]

20. Shamshad, A. The development of integrated pest management for the control of mushroom sciarid flies, Lycoriella ingenua (Dufour) and Bradysia ocellaris (Comstock), in cultivated mushrooms. Pest Manag. Sci. 2010, 66, 1063-1074. [CrossRef] [PubMed]

21. Shirvani-Farsani, N.; Zamani, A.A.; Abbasi, S.; Kheradmand, K. Toxicity of three insecticides and tobacco extract against the fungus gnat, Lycoriella auripila and the economic injury level of the gnat on button mushroom. J. Pestic. Sci. 2013, 86, 591-597. [CrossRef]

22. Lee, B.-J.; Lee, M.-A.; Kim, Y.-G.; Lee, S.-G.; Lee, B.-E.; Seo, G.-S. Occurrence and control of mushroom flies during Agaricus bisporus cultivation in Chungnam, Korea. J. Mushrooms 2016, 14, 100-104. [CrossRef]

23. Andreadis, S.S.; Cloonan, K.R.; Bellicanta, G.S.; Paley, K.; Pecchia, J.; Jenkins, N.E. Efficacy of Beauveria bassiana formulations against the fungus gnat Lycoriella ingenua. Biol. Control 2016, 103, 165-171. [CrossRef]

24. Sharma, S.R. Plant protection operations in mushroom production. In Advances in Mushroom Biology and Production; Rai, R.D., Dhar, B.L., Verma, R.N., Eds.; MSI: Solan, India, 1997; pp. 209-224.

25. Erler, F.; Polat, E.; Demir, H.; Cetin, H.; Erdemir, T. Control of the mushroom phorid fly, Megaselia halterata (Wood), with plant extracts. Pest Manag. Sci. 2009, 65, 144-149. [CrossRef] [PubMed]

26. Navarro, M.J.; Escudero, A.; Ferragut, F.; Gea, F.J. Evolution and seasonal abundance of phorid and sciarid flies in Spanish mushroom crops. In Proceedings of the 4th International Conference on Mushroom Biology and Mushroom Products, Cuer-Navaca, México; Sánchez, E., Huerta, G., Montiel, E., Eds.; Talleres Jupiter: Morelos, Mexico, 2002; pp. 189-195. 
27. Baars, J.; Rutjens, J.; de Kogel, W.J.; Baars, J. The use of plant extracts to control the major disease and pest in mushroom cul-tivation. In Science and Cultivation of Edible and Medicinal Fungi, Proceedings of the 17th Congress of the International Society for Mushroom Science, Pretoria, South Africa, 20-24 May 2008; Van Greuning, M., Ed.; University of Minnesota: Minneapolis, MN, USA, 2008; pp. 602-614.

28. Bhattacharyya, P.R.; Adhikary, R.K.; Bordoloi, D.N. Population dynamics of insect pests and damage of the white button mushroom in the environment of North Eastern India. Indian J. Food Sci. Technol. 1993, 30, 377-379.

29. Joshi, G. Screening of Oyster Mushroom, Pleurotus spp. against Mushroom Flies and Their Management. Ph.D. Thesis, Department of Entomology College of Agriculture, Ccs Haryana Agricultural University, Hisar, South Africa, 2009.

30. Mazin, M. Mushroom Flies and Farm Workers: Fly Ecology and Vector Competency and IPM Implementation among Hispanic Mushroom Farmworkers. Ph.D. Thesis, The Pennsylvania State University, University Park, PA, USA, 2018; p. 171. Available online: https: / / etda.libraries.psu.edu/files / final_submissions/18179 (accessed on 20 September 2021).

31. Mazin, M.; Andreadis, S.S.; Jenkins, N.E.; Cloonan, K.R.; Baker, T.; Rajotte, E.G. Activity and distribution of the mushroom phorid fly, Megaselia halterata, in and around commercial mushroom farms. Entomol. Exp. et Appl. 2019, 167, 389-395. [CrossRef]

32. Shikano, I.; Woolcott, J.; Cloonan, K.; Andreadis, S.; Jenkins, N.E. Biology of Mushroom Phorid Flies, Megaselia halterata (Diptera: Phoridae): Effects of Temperature, Humidity, Crowding, and Compost Stage. Environ. Èntomol. 2020, 50, 149-153. [CrossRef]

33. Disney, R. Natural History of the Scuttle Fly, Megaselia scalaris. Annu. Rev. Èntomol. 2008, 53, 39-60. [CrossRef]

34. Moreton, B.D. Mushroom flies in Britain in 1956. In Mushroom Science III. Proceedings of the 3th International Conference on Biology and Mushroom Growing; Le Réveil Lochois: Loches, France, 1956; pp. 102-103.

35. Grewal, P.F. Mushroom pest. In Field Manual of Techniques in Invertebrate Pathology; Lacey, L.A., Kaya, H.K., Eds.; Springer: Berlin/Heidelberg, Germany, 2007; pp. 457-461.

36. Hussey, N.W. Biology of mushroom phorids. In Mushroom Science IV. Proceedings of the IVth International Conference on Scientific Aspects of Mushroom Growing; International Commision Mushroom Science: Copenhague, Denmark, 1959; pp. $260-270$.

37. Clift, A.D. The identity, economic importance and control of insect pests of mushroom in New South Wales, Australia. In Mushroom Science X. Proceedings of the 10th International Congress of Science and Cultivation of Edible Fungi, Bordeaux, France; Delmas, J., Ed.; FAO: Rome, Italy, 1978; pp. 367-383.

38. Binns, E.S. Mating behaviour, fecundity and feeding in the mushroom phorid Megaselia halterata (Wood) (Dipt.). Entomol. Mon. Mag. 1980, 116, 45-48.

39. Thomas, C.A. Animal pests of cultivated mushrooms in The United States. Mushroom Science IV. In Proceedings of the 4th International Conference on Scientific Aspects of Mushroom Growing, Copenhague, Denmark, 18-26 July 1959 ; pp. 400-410.

40. Kumar, P. Screening of White Button Mushroom, Agaricus Bisporus (Lange) Singer Strains against Mushroom Flies and Their Management through Botanicals. Ph.D. Thesis, Department of Entomology College of Agriculture, CCS Haryana Agricultural University, Hisar, South Africa, 2005.

41. Bellettini, M.B.; Bellettini, S.; Fiordac, F.A.; Pedroa, A.C.; Bacha, F.; Fabela-Morónd, M.F.; Hoffmann-Ribania, R. Diseases and pests noxious to Pleurotus spp. mushroom crops. Rev. Argent. Microbiol. 2018, 50, 216-226. [CrossRef] [PubMed]

42. White, P.F. Pests and pesticides. In The Biology and Technology of the Cultivated Mushroom; Flegg, P.B., Spencer, D.M., Wood, D.A., Eds.; John Wiley and Sons: New York, NY, USA, 1985; pp. 279-293.

43. Rinker, D.L.; Snetsinger, R.J. Damage threshold to a commercial mushroom by a mushroom-infesting phorid (Diptera: Phor-idae). J. Econ. Entomol. 1984, 77, 449-453. [CrossRef]

44. Lewandowski, M.; Kozak, M.; Sznyk-Basałyga, Y.G.A. Biology and morphometry of Megaselia halterata, an important insect pest of mushrooms. Bull. Insect. 2012, 65, 1-8.

45. Disney, R.H.L. Scuftle Flies: The Phoridae; Chapman and Hall: London, UK, 1994.

46. Krishnamoorthy, A.S.; Marimuthu, T.; Sivaprakasam, K.; Jeyarajan, R. Ocurrence and damage caused by phorid fly on Oyster mushroom. Mushroom J. Tropics 1991, 11, 23-27.

47. Barh, A.; Kamal, S.; Kumari, B.; Annepu, S.K.; Kumar, S.; Shirur, M.; Sharma, V. Effects of Nitrogen Supplementation With Wheat Straw on Productivity of Pleurotus djamor (Rumph. Ex FR.) Boedijn. Bangladesh J. Bot. 2021, 50, 227-233. [CrossRef]

48. Navarro, M.J.; López-Serrano, F.R.; Escudero-Colomar, L.A.; Gea, F.J. Cultivation of Agaricus bitorquis mushroom as an strategy for the Integrated Pest Management of the myceliophagous mite Microdispus lambi. Pest Manag. Sci. 2020, 76, 2953-2958. [CrossRef]

49. White, P.F.; Smith, J.E.; van Griensven, L.J.L.D. Population development of mushroom pests of species and strains of Agaricus, In Science and Cultivation of Edible Fungi. Proceedings of the 15th International Congress on the Science and Cultivation of Edible Fungi, Maastricht, Netherlands; van Griensven, L.J.L.D., Ed.; Baalkema: Rotterdam, The Netherlands, 2000; pp. 707-712.

50. Smith, J.; Challen, M.; White, P.; Edmondson, R.; Chandler, D. Differential effect of Agaricus host species on the population development of Megaselia halterata (Diptera: Phoridae). Bull. Èntomol. Res. 2006, 96, 565-571. [CrossRef]

51. Hussey, N.W.; Read, W.H.; Hesling, J.J. Insect pests of mushroom. In The Pest of Protected Cultivation. The Biology and Control of Glasshouse and Mushroom Pests; Edward Arnold Publisher Ltd.: London, UK, 1969; pp. 305-307.

52. Binns, E.S.; Gurney, B.; Wyatt, I.J.; White, P.F. Populations of the phorid fly Megaselia halterata on an experimental mushroom unit over four years. Ann. Appl. Biol. 1979, 92, 159-171. [CrossRef]

53. Kumar, S.; Sharma, S.R. Studies on seasonal abundance of mushroom pests. Mushroom Res. 2001, 10, $121-123$.

54. Kumar, S.; Sharma, S.R. Insects and pests of Agaricus bisporus (Lange) Singer and their management. In Recent Advances in the Cultivation Technology of Edible Mushrooms; Verma, R.N., Vijay, B., Eds.; Springer: Berlin/Heidelberg, Germany, 2002; pp. 177-199. 
55. Grove, J.F.; Blight, M.M. The oviposition attractant for the mushroom phorid Megaselia halterata: The identification of volatiles presented in mushroom house air. J. Sci. Food Agric. 1983, 34, 181-185. [CrossRef]

56. Pfeil, R.M.; Mumma, R.O. Bioassay for evaluating attraction of the phorid fly, Megaselia halterata to compost colonized by the commercial mushroom, Agaricus bisporus and to 1-octen-3-ol and 3-octanone. Ėntomol. Exp. et Appl. 1993, 69, 137-144. [CrossRef]

57. Hussey, N.W.; Wyatt, I.J. The interaction between mushroom mycelium and insect pest populations. In Mushroom Science V, Proceedings of the 5th International Conference on Scientific Aspects of Mushroom Growing, Philaphelpia, Pennsylvania, USA; Campbell Soup Company: Camden, NJ, USA, 1962; pp. 509-517.

58. Wallingford, A.K.; Hesler, S.P.; Cha, D.H.; Loeb, G.M. Behavioral response of spotted-wing drosophila, Drosophila suzukii Matsumura, to aversive odors and a potential oviposition deterrent in the field. Pest Manag. Sci. 2015, 72, 701-706. [CrossRef]

59. Stockton, D.G.; Wallingford, A.K.; Cha, D.H.; Loeb, G.M. Automated aerosol puffers effectively deliver 1-octen-3-ol, an oviposition antagonist useful against spotted-wing drosophila. Pest Manag. Sci. 2020, 77, 389-396. [CrossRef]

60. Cui, K.; Yang, S.; Zou, N.; He, L.; Zhang, T.; Liu, F.; Mu, W. Residual behavior of the potential grain fumigant 1-octen-3-ol in wheat during fumigation and ventilation processes. Pest Manag. Sci. 2021, 77, 2933-2938. [CrossRef]

61. Finley, R.J.; Wuest, P.J.; Royse, D.J.; Snetsinger, R.J.; Tetrault, R.; Rinker, D.L. Mushroom flies. Mushroom J. 1984, $139,240-247$.

62. Scheepmaker, J.W.A.; Geels, F.P.; Smits, P.H.; van Griensven, L.J.L.D. Location of inmature stages of the mushroom insects pest Megaselia halterata in mushroom-growing medium. Entomol. Exp. Appl. 1997, 83, 323-327. [CrossRef]

63. Hussey, N.W. Cultural innovation: Its implications for mushroom pest control. In Mushroom Science XI. Proceedings of the 11th International Congress of Science and Cultivation of Edible Fungi, Sideny, Australia; Nair, N.G., Ed.; FAO: Rome, Italy, 1981; pp. 523-536.

64. Richardson, P.N.; Heshing, J.J. Laboratory rearing of the mushroom phorid Megaselia halterata (Diptera: Phoridae). Ann. Appl. Biol. 1978, 88, 211-217. [CrossRef]

65. Hussey, N.W.; Gurney, B. Rearing Techniques for Mushroom Fly. Plant Pathol. 1964, 13, 38-39. [CrossRef]

66. Martín, A.; Gea, F.J.; Navarro, M.J. Champiñón y Setas In Guía de Gestión Integrada de Plagas; Ministerio de Agricultura; Pesca y Alimentación y Medio Ambiente: Madrid, Spain, 2016; p. 136.

67. Zamani, A.A. Identification of Injurious Dipterean Pest of Button Mushroom (Agaricus bisporus) and Study on Some of Their Biological Characteristics in Karaj, Iran. Master's Thesis, Razi University, Kermanshah, Iran, 2001.

68. Barzegar, S.; Zamani, A.A.; Abbasi, S.; Shooshtari, R.V.; Farsani, N.S. Temperature-Dependent Development Modeling of the Phorid Fly Megaselia halterata (Wood) (Diptera: Phoridae). Neotropical Èntomol. 2016, 45, 507-517. [CrossRef] [PubMed]

69. White, P.F. The mushroom pest complex-Its affect on yield and quality. In Cultivating Edible Fungi; Wuest, P.J., Royse, D.J., Beelman, R.B., Eds.; Elsevier: Amsterdam, The Netherlands, 1987; pp. 301-310.

70. Jess, S.; Kilpatrick, M. An integrated approach to the control of Lycoriella solani (Diptera: Sciaridae) during production of the cultivated mushroom (Agaricus bisporus). Pest Manag. Sci. 2000, 56, 477-485. [CrossRef]

71. Hussey, N.W.; Wyatt, I.J.; Hughes, J.T. Insecticidal control of paedogenic cecid larvae in mushroom beds. Incorporation of insecticides into compost. Ann. Appl. Biol. 1960, 48, 336-346. [CrossRef]

72. Hernández-Rodríguez, D.; Sanchez, J.E.; Nieto, M.G.; Márquez-Rocha, F.J. Degradation of endosulfan during substrate preparation and cultivation of Pleurotus pulmonarius. World J. Microbiol. Biotechnol. 2006, 22, 753-760. [CrossRef]

73. Bartlett, G.R.; Keil, B.O.C. Identification and characterization of a permethrine resistence mechanism in populations of the fungus gnat Lycoriella mali (Fitch) (Diptera: Sciaridae). Pestic. Biochem. Physiol. 1997, 58, 173-181. [CrossRef]

74. Cantelo, W.W. Control of Megaselia halterata, a phorid fly pest of commercial mushroom production, by insecticidal treatment of the compost or casing material. J. Entomol. Sci. 1985, 85, 50-54. [CrossRef]

75. Grewal, P.S.; Sohi, H.S. Studies on the effect of different pesticides on the growth of Agaricus bisporus (Lange) Singer and Pleurotus sajorcaju (Fr.) Singer. Mushroom J. Tropics 1987, 7, 25-29.

76. Dmoch, J. Effect of Some Insecticides on Mushroom Mycelial Growth. Acta Hortic. 1988, 15-20. [CrossRef]

77. White, P.F. The comparative effects of three formulations of diazinon on cropping of a hybrid and a non-hybrid strain of the cultivated mushroom Agaricus bisporus. Ann. Appl. Biol. 1992, 121, 655-668. [CrossRef]

78. Navarro, M.J.; Merino, L.; Gea, F.J. Evaluation of residue risk and toxicity of different treatments with diazinon insecticide applied to mushroom crops. J. Environ. Sci. Health Part B 2017, 52, 218-221. [CrossRef]

79. Bhandari, T.P.S.; Singh, R.N.; Bisht, T.S.; Kanaujia, J.P. Effect of diazinon on control of two mushroom flies of button mushroom (Agaricus brunnescens). Prog. Hortic. 1989, 21, 119-122.

80. Sandhu, G.S.; Bhattal, D.S. Chemical control of phorid fly, Megaselia sandhui Disney and its effect on the yield of white button mushroom. Mushroom J. Trop. 1989, 9, 115-120.

81. White, P.F. Effects of bendiocarb and diflubenzuron on mushroom cropping. Ann. Appl. Biol. 1986, 108, 11-20. [CrossRef]

82. Wei, M.-Q.; Sha, L.-J.; Lan, S.-S.; Zhang, Y.; Lin, T.; Lin, X.; Yang, J.; Liu, H.-C. Effects of five insecticides on phorid flies and their residue analysis in Pleurotus ostreatus. J. Food Saf. Qual. 2018, 9, 5993-5997.

83. Geels, F.P.; Rutjens, A.J. Bendiocarb and diflubenzuron as susbtitute insecticides for endosulfan in commercial mushroom growing. Ann. Appl. Biol. 1992, 120, 215-224. [CrossRef]

84. Sandhu, G.S.; Arora, P.K. Studies on mechanical and chemical control of mushroom flies, important pests of white button mushroom in Punjab. J. Insect Sci. 1990, 3, 92-96. 
85. Grewal, P.S.; Tomalak, M.; Keil, C.B.O.; Gaugler, R. Evaluation of a genetically selected strain of Steinernema feltiae against the mushroom sciarid Lycoriella mali. Ann. Appl. Biol. 1993, 123, 695-702. [CrossRef]

86. Navarro, M.J.; Gea, F.J. Entomopathogenic nematodes for the control of phorid and sciarid flies in mushroom crops. Pesqui. Agropec. Brasileira 2014, 49, 11-17.

87. Jess, S.; Bingham, J. Biological control of sciarid and phorid pests of mushroom with predatory mites from the genus Hypoaspis (Acari: Hypoaspidae) and the entomopathogenic nematode Steinernema feltiae. Bull. Ėntomol. Res. 2004, 94, 159-167. [CrossRef] [PubMed]

88. Grewal, P.S.; Richardson, P.N.; Collins, G.; Edmondson, R.N. Comparative effects of Steinernema feltiae (Nematoda: Steinernematidae) and insecticides on yield and cropping of the mushroom Agaricus bisporus. Ann. Appl. Biol. 1992, 121, 511-520. [CrossRef]

89. Koppenhöfer, A.M.; Grewal, P.S. Compatibility and interactions with agrochemicals and other biocontrol agents. In Nematodes as Biocontrol Agents; CABI: New York, NY, USA, 2005; pp. 363-381.

90. Keil, C.B.O. Field and laboratory evaluation of Bacillus thuringiensis var. israelensis formulation for the control of the fly pests of mushrooms. J. Econ. Entomol. 1991, 84, 1180-1188. [CrossRef]

91. Gill, R.S.; Sandhu, G.S.; Dhooria, M.S. Studies on the pest and predatory status of mite Parasitus consanguineus Oudemans \& Voigts (Parasitidae: Mesostigmata: Acari) occurring in Punjab. Indian J. Mushrooms 1988, 14, 32-36.

92. Szlendak, E.; Lewandowski, M. Development and reproductive capacity of the predatory mite Parasitus consanguineus (Acari: Parasitidae) reared on the larval stages of Megaselia halterata and Lycoriella ingenua. Exp. Appl. Acarol. 2009, 47, 285-292. [CrossRef]

93. Andreadis, S.S.; Cloonan, K.R.; Bellicanta, G.S.; Jenkins, N.E. Efficacy of BotaniGard ${ }^{\circledR}$ against the mushroom phorid fly Megaselia halterata. Biocontrol Sci. Technol. 2021, 1-9. [CrossRef]

94. Geösel, A.; Szabó, A.; Akan, O.; Szarvas, J. Effect of essential oils on mycopathogens of Agaricus bisporus. In Proceedings 8th Conference of Mushroom Biology and Mushroom Products; ICAR-DMR, Solan HP \& WSMBMP: New Delhi, India, 2014; pp. 530-535.

95. Cetin, H.; Cinbilgel, I.; Yanikoglu, A.; Gokceoglu, M. Larvicidal activity of some labiatae (lamiaceae) plant extracts from Turkey. Phytother. Res. 2006, 20, 1088-1090. [CrossRef]

96. Shamshad, A.; Clift, A.D.; Mansfield, S. Toxicity of six commercially formulated insecticides and biopesticides to third instar larvae of mushroom sciarid, Lycoriella ingenuaDufour (Diptera: Sciaridae), in New South Wales, Australia. Aust. J. Ėntomol. 2008, 47, 256-260. [CrossRef]

97. Gholamzadeh-Chitgar, M.; Hajizadeh, J.; Ghadamyari, M.; Karimi-Malati, A.; Hoda, H. Effects of sublethal concentration of diazinon, fenitrothion and chlorpyrifos on demographic and some biochemical parameters of predatory bug, Andrallus spinidens Fabricius (Hemiptera: Pentatomidae) in laboratory conditions. Int. J. Pest Manag. 2015, 61, 1-8. [CrossRef]

98. OJ. Directive 2007/393/CEE of the Council of June 6. Official Journal of the European Union L 148 09/06/2007a. Directive 2007/39/CEE of the Council. pp. 9-10. Available online: https:/ / www.boe.es/doue/2007/165/L00025-00032.pdf (accessed on 20 September 2021).

99. Jacewicz, D.J.; Bykowska, E. Effect of some IGR insecticides on mushroom mycelial growth. In Mushroom Science XIII. Proceedings of the 13th International Congress of Science and Cultivation of Edible Fungi; FRG: Braunschweig, Germany, 1989 ; pp. 877-882.

100. Clift, A.D.; Terras, M.A. Evaluation of two insect growth regulators for insect pest control in the Australian mushroom in-dustry. Plant Prot. Q. 1992, 7, 59-61.

101. Shamshad, A.; Clift, A.D.; Mansfield, S. Effect of compost and casing treatments of insecticides against the sciarid Bradysia ocellaris Comstock (Diptera: Sciaridae) and on the total yield of cultivated mushrooms, Agaricus bisporus Imbach. Pest Manag. Sci. 2009, 65, 375-380. [CrossRef]

102. Erler, F.; Polat, E.; Demir, H.; Catal, M.; Tuna, G. Control of mushroom sciarid fly Lycoriella ingenua populations with insect growth regulators applied by spil drench. J. Econ. Entomol. 2011, 104, 839-844. [CrossRef] [PubMed]

103. Navarro, M.J.; Gea, F.J. Estudio de la fitotoxicidad del insecticida diflubenzuron en el cultivo de champiñón. Determinación del nivel de residuos. Bol. Asoc. Española De Cultiv. De Champiñón 2006, 48, 32-34.

104. Navarro, M.J.; Carrasco, J.; Gea, F.J. Chemical and biological control of diptera in Spanish mushroom crops. In Proceedings of the 8th International Conference on Mushroom Products (ICMBMP8), New Delhi, India, 19-22 November 2014; pp. 549-556.

105. The Directive 2009/128/EC. Available online: https://boe.es/doue/2009/309/L00071-00086.pdf (accessed on 20 September 2021).

106. Scheepmaker, J.W.A.; Geels, F.P.; Rutjens, A.J.; Smits, P.H.; van Griensven, L.J.L.D. Comparison of the efficacy of entomopathogenic nematodes for the biological control of the mushrooms pests Lycoriella auripila (Sciaridae) and Megaselia halterata (Phoridae). Biocon. Sci. Technol. 1998, 8, 277-288. [CrossRef]

107. Holtz, R.B.; Markowitz, N.; Spruce, B. Development of an effective delayed release pesticide for control of sciarid flies. In Mushroom Science XI. Proceedings of the 11th International Congress of Science and Cultivation of Edible Fungi, Sideny, Australia; Nair, N.G., Ed.; FAO: Rome, Italy, 1981; pp. 551-561.

108. Zhang, Q.; Wang, X.; Rao, Q.; Chen, S.; Song, W. Imidacloprid dissipation, metabolism and accumulation in Agaricus bisporus fruits, casing soil and compost and dietary risk assessment. Chemosphere 2020, 254, 126837. [CrossRef] [PubMed]

109. Schulz, R.; Bub, S.; Petschick, L.L.; Stehle, S.; Wolfram, J. Applied pesticide toxicity shifts toward plants and invertebrates, even in GM crops. Science 2021, 372, 81-84. [CrossRef] 
110. Richardson, P.N. Susceptibility of mushroom pests to the insect-parasitic nematodes Steinernema feltiae and Heterorhabditis heliothidis. Ann. Appl. Biol. 1987, 111, 433-438. [CrossRef]

111. Kirk, D.J.; Keil, C.B. Factors influencing efficacy of two entomopathogenic nematodes used for fly control in commercial mushroom crops. Mushroom News 2001, 49, 4-17.

112. Shapiro-Ilan, D.; Gouge, D.; Piggott, S.J.; Fife, J.P. Application technology and environmental considerations for use of entomopathogenic nematodes in biological control. Biol. Control. 2006, 38, 124-133. [CrossRef]

113. Edmunds, C.; Wilding, C.S.; Rae, R. Pathogenicity and environmental tolerance of commercial and UK native entomopath-ogenic nematodes (Steinernema and Heterorhabditis spp.) to the larvae of mosquitoes (Aedes aegypti and Ochlerotatus de-tritus). Int. J. Pest Manag. 2020, 67, 1-9.

114. Scheepmaker, J.W.A.; Geels, F.P.; Smits, P.H.; Van Griensven, L.J.L.D. Control of the mushroom pests Lycoriella auripila (Diptera: Sciaridae) and Megaselia halterata (Diptera: Phoridae) by Steinernema feltiae (Nematoda: Steinernematidae) in field experiments. Ann. Appl. Biol. 1997, 131, 359-368. [CrossRef]

115. Acharya, R.; Hwang, H.-S.; Shim, J.-K.; Yu, Y.-S.; Lee, K.-Y. Control efficacy of fungus gnat, Bradysia impatiens, enhanced by a combination of entomopathogenic nematodes and predatory mites. Biol. Control. 2019, 138. [CrossRef]

116. Duarte Neto, J.M.W.; de Wanderley, M.C.A.; da Silva, T.A.F.; Viana Marques, D.A.; da Silva, G.R.; Fernandes Gurgel, J.; de Paula Oliveira, J.F.; Porto, A.L.F. Bacillus thuringiensis endotoxin production: A systematic review of the past 10 years. World J. Microbiol. Biotechnol. 2020, 36, 128. [CrossRef] [PubMed]

117. Cantwell, G.E.; Cantelo, W.W. Effectiveness of Bacillus thuringiensis var. israelensis in Controlling a Sciarid Fly, Lycoriella mali, in Mushroom Compost. J. Econ. Èntomol. 1984, 77, 473-475. [CrossRef]

118. White, P.F.; Butt, P.; Pethybridge, N.J. The story of a strain: Development of GC327, a dipteran-active strain of, Bacillus thuringiensis effective against the mushroom sciarid, Lycoriella auripila. In Mushroom Science XIV. Science and Cultivation of Edible Fungi. Proceedings of the 14th International Congress of Science and Cultivation of Edible Fungi; Elliot, T.J., Ed.; August Aimé Balkema: Rotterdam, The Netherlands, 1995; pp. 499-506.

119. Keil, C.B. Interaction of Agaricus bisporus with Bacillus thuringiensis var. israelensis applied for control of Lycoriella mali. In Mushroom Science XIV. Science and Cultivation of Edible Fungi. Proceedings of the 14th International Congress of Science and Cultivation of Edible Fungi; August Aimé Balkema: Rotterdam, The Netherlands, 1995; pp. 525-532.

120. Keil, C.B.; White, P.F. Biological Control for Mushroom Production. In BioControl in Protected Culture; Ball Publishing: West Chicago, IL, USA, 2004; pp. 473-484.

121. Knapp, M.; van Houten, Y.; van Baal, E.; Groot, T. Use of predatory mites in commercial biocontrol: Current status and future prospects. Acarologia 2018, 58 (Suppl.), 72-82. [CrossRef]

122. Enkegaard, A.; Sardar, M.A.; Brodsgaard, H.F. The predatory mite Hypoaspis miles: Biological and demographic characteristics on two prey species, the mushroom sciarid fly, Lycoriella solani, and the mould mite, Tyrophagus putrescentiae. Entomol. Exp. Appl. 1997, 82, 135-146. [CrossRef]

123. Jess, S.; Schweitzer, H. Biological control of Lycoriella ingenua (Diptera: Sciaridae) in commercial mushroom (Agaricus bisporus) cultivation: A comparison between Hypoaspis miles and Steinernema feltiae. Pest Manag. 2009, 65, 1195-1200. [CrossRef]

124. Khan, S.; Guo, L.; Maimaiti, Y.; Mijit, M.; Qiu, D. Entomopathogenic Fungi as Microbial Biocontrol Agent. Mol. Plant Breed. 2012, 3. [CrossRef]

125. Keil, C.B.O.; Bartlett, G.R. Azatin for control of Lycoriella mali in Agaricus mushroom production. Mushroom News 1995, 43, 10-13.

126. Steinhauerm, B. Fungicidal activity of commercial neem products. In Practice Oriented Results on Use and Production of Neem Ingredients and Pheromones; Kleeberg, H., Micheletti, V., Eds.; Druck \& Graphic: Giessen, Germany, 1996; pp. $105-116$.

127. Jess, S.; Kirbas, J.M.; Gordon, A.W.; Murchie, A.K. Potential for use of garlic oil to control Lycoriella ingenua (Diptera: Sciar-idae) and Megaselia halterata (Diptera: Phoridae) in commercial mushroom production. Crop Prot. 2017, 102, 1-9. [CrossRef]

128. Isman, M.B. Plant essential oils for pest and disease management. Crop. Prot. 2000, 19, 603-608. [CrossRef]

129. Park, I.K.; Choi, K.S.; Kim, D.H.; Choi, I.H.; Kim, L.S.; Bak, W.C.; Choi, J.; Shin, S.C. Fumigant activity of plant essential oils and components from horseradish (Armoracia rusticana), anise (Pimpinella anisum) and garlic (Allium sativum) oils against Lycoriella ingenua (Diptera: Sciaridae). Pest Manag. Sci. 2006, 62, 723-728. [CrossRef] [PubMed]

130. Park, I.K.; Kim, L.S.; Choi, I.H.; Lee, Y.S.; Shin, S.C. Fumigant activity of plant essential oils and components from Schizonepeta tenuifolia against Lycoriella ingenua (Diptera: Sciaridae). Hortic. Entomol. 2006, 99, 1717-1721.

131. Coles, P.S. Specific control techniques. In Exclusion in Pennsylvania Mushroom Integrated Pest Management; The Pennsylvania State University: State College, PA, USA, 2002; 92p.

132. Carrasco, J.; Zied, D.C.; Navarro, M.J.; Gea, F.J.; Pardo-Giménez, A. Commercial Cultivation Techniques of Mushrooms. In Advances in Macrofungi; CRC Press: Boca Raton, FL, USA, 2021; pp. 11-40. [CrossRef] 